\title{
Uma reflexão sobre as igrejas isocristãs à luz do pensamento sobre o "demônico" em Paul Tillich
}

\author{
A reflection on isochristian Churches in the light of Paul
}

Tillich's thought of the "Demonic"

JAZIEL GUERREIRO MARTINS ${ }^{a}$

\section{Resumo}

Este artigo tem como objetivo fazer uma análise teológica de dois grupos religiosos em solo brasileiro identificados como "isocristãos", a partir do pensamento do "demônico" em Paul Tillich. Principia-se argumentando como poderiam ser classificados determinados grupos dentro do neopentecostalismo, identificando as Igrejas Universal do Reino de Deus e Mundial do Poder de Deus como grupos não cristãos. Tenta-se demonstrar de forma introdutória que grupos religiosos como estes não podem mais ser considerados como neopentecostais, mas como algo parecido; destarte, estas seriam igrejas isocristãs. Em seguida, inicia-se uma elocubração teológica a partir da ideia de Tillich sobre o "demônico", explicando a relação deste pensamento tillichiano com estas igrejas isocristãs, haja vista que a demonologia e a demonopráxis tem sido o elemento hermenêutico central comum ao redor do qual gravitam todas as doutrinas e práticas litúrgicas do movimento. Por fim, ao se demonstrar à luz do pensamento de Paul Tillich as ambiguidades destas, acaba por apresentar que uma igreja é uma comunidade de paz e amor, diverso do pensamento das duas igrejas em análise as quais procuram diabolizar e esconjurar a religião do outro.

Palavras-chave: Demônico. Tillich. Isocristão. Igreja Universal. Igreja Mundial.

\footnotetext{
a Faculdades Batista do Paraná (FABAPAR), Curitiba, PR, Brasil. Doutor em Ciências da religião, e-mail: martinsjaziel@hotmail.com
} 


\section{Abstract}

This article aims to make a theological analysis of two religious groups in Brazil identified as "isochristian", from the perspective of Paul Tillich's thought on the "demonic". It begins by discussing how certain groups could be classified amidst neo-Pentecostalism, identifying two churches, Igreja Universal do Reino de Deus and Igreja Mundial do Poder de Deus, as non-Christian groups. We attempt to introduce a demonstration that religious groups like these can no longer be considered neopentecostal, but something alike to it; thus, these would be isochristian churches. We then begin a theological reflection from Tillich's idea of the "demonic", explaining the relationship between this Tillichian thought and these isochristian churches, since demonology and demonopraxis have been the common core hermeneutic element around which gravitates every doctrine and practice of the mentioned churches. At last, by demonstrating the ambiguities of said churches under the light of Paul Tillich's thought, we present that a church is a community of peace and love, different from the thinking of the two churches under analysis, which seek to demonize and disqualify other people's religions.

Keywords: Demonic. Tillich. Isochristian churches. Neo-Pentecostal movement.

\section{Introdução}

O século XXI tem tido enormes transformações no campo da fé, com mudanças e nuances significativas na religiosidade brasileira. A Igreja Universal do Reino de Deus (IURD), por exemplo, introduziu novos elementos antes não praticados em solo brasileiro, marcando uma mudança de paradigma entre determinados grupos do seguimento pentecostal que tem se desenvolvido em várias outras igrejas nas duas primeiras décadas do novo milênio, atingindo até mesmo certos segmentos do cognominado protestantismo histórico. A IURD historicamente pertenceu ao grupo de igrejas surgidas no último quarto do século XX no Brasil, as quais foram conhecidas entre os estudiosos como Igrejas Neopentecostais ${ }^{1}$.

\footnotetext{
${ }^{1}$ Alguns autores, tais como José Bittencourt Filho, ligado ao antigo CEDI (Centro Ecumênico de Documentação e Informação) do Rio de Janeiro, Ari Pedro Oro, da Universidade Federal
} 
Com o surgimento da Igreja Mundial do Poder de Deus (IMPD) no início deste milênio, a qual nasceu com um ex-bispo da IURD, o atual Apóstolo Santiago, agitou-se a onda neopentecostal e novos territórios foram demarcados, fazendo até o próprio bispo Macedo mudar sua práxis religiosa para estancar a perda de fiéis, introduzindo novos elementos religiosos, especialmente do judaísmo veterotestamentário, representado pela construção do famoso e suntuoso templo do Rei Salomão na cidade de São Paulo. E assim alguns grupos do neopentecostalismo vão se reinventando para atender a sua sede mercadológico-financeira e sua demarcação territorial. Como consequência, ao mesmo tempo em que há uma pulverização dos grupos mais históricos dentro do mundo evangélico, há uma nova territorialização, mais recente, surgida e desenvolvida com ímpeto até descomunal.

\section{Grupos Isocristãos}

Até a virada do milênio, em solo brasileiro, o pentecostalismo poderia ser dividido em três fases, que alguns autores chamavam de ondas ${ }^{2}$. Freston foi o primeiro a dividir o movimento pentecostal em ondas: ele entendia o pentecostalismo brasileiro como a história de três ondas de implantação de

do Rio Grande do Sul e Jesus Hortal, da PUC do Rio de Janeiro, usaram o termo "Pentecostalismo Autônomo" para designar aqueles grupos pentecostais fundados e liderados no final dos anos 70 e início dos anos 80 por empreendedores e líderes carismáticos que preferiram se estabelecer por conta própria, sem vínculos, inclusive com as missões estrangeiras. Já Ricardo Mariano, Leonildo Silveira Campos, Alberto Antoniazzi e Antonio Gouveia Mendonça, dentre outros, preferem usar o termo "Neopentecostalismo". A própria Igreja Universal do Reino de Deus entitula-se como neopentecostal. Na Folha Universal de 11.6.95, Luiz C. Almeida, ao referir-se sobre a IURD como tal, diz que o "neopentecostalismo é um ramo do pentecostalismo".

2 Paul Freston, ao analisar as transformações ocorridas na prática política dos protestantes brasileiros, discutiu o fenômeno religioso a partir das "três ondas" pentecostais, desenvolvendo categorias de periodização inspiradas em David Martin e Peter Wagner. Em tal periodização e classificação, Freston coloca em primeiro lugar o "Pentecostalismo Clássico", fruto da primeira onda, que foi lentamente fluindo até chegar à segunda onda, que seriam os movimentos de "cura divina", culminado com a terceira onda, que seria o "Pentecostalismo Autônomo" ou o "Neopentecostalismo". 
igrejas. A primeira onda seria a década de 1910, com a chegada da Congregação Cristã (1910) e da Assembleia de Deus (1911). A segunda onda pentecostal seria dos anos 50 e início de 60, na qual o campo pentecostal se fragmenta, a relação com a sociedade se dinamiza a três grandes grupos (em meio a dezenas de menores) surgem: a Quadrangular (1951), Brasil para Cristo (1955) e Deus é Amor (1962). O contexto dessa pulverização seria paulista. A terceira onda começaria no final dos anos 70 e ganharia força nos anos 80 . Suas principais representantes seriam a Igreja Universal do Reino de Deus (1977) e a Igreja Internacional da Graça de Deus, em um contexto fundamentalmente carioca ${ }^{3}$.

Passadas duas décadas de intensas agitações e disputas entre alguns grupos do neopentecostalismo brasileiro para o estabelecimento do território de cada um, percebe-se que já não se pode mais alcunhar alguns grupos como sendo neopentecostais, mas que advindos do neopentecostalismo, se transmutaram de acordo com a necessidade de manutenção e desenvolvimento de poder, enriquecimento de seus líderes e dominação de território religioso, em um novo tipo de religiosidade que não pode mais ser alcunhada de neopentecostalismo. São algo diferente, não mais como eram. Não podem mais ser classificados como antes.

Várias designações têm surgido para explicar o fenômeno e cada estudioso o explica dentro de sua área do saber científico e de sua própria concepção do movimento, trazendo luz e clareza aos acadêmicos e sequiosos pelo conhecimento científico acerca do movimento religioso brasileiro. Nomes como "Religiões Pós-cristãs", "Religiões Acristãs", "Religiões Isopentecostais", "Grupos Pseudocristãos" tem se ouvido falar no mundo acadêmico. Embora sendo Cientista da Religião e Teólogo, percebo muita coisa sendo escrita para explicar esse fenômeno sob a luz da Sociologia e das Ciências da Religião e quase nada sob o ângulo da Teologia. O que teria a Teologia a contribuir nessa área específica do conhecimento sobre essa nova configuração religiosa?

Teologicamente, o nome mais adequado no momento para designar essa nova configuração religiosa seria o uso do radical grego "iso" acrescida à

\footnotetext{
${ }^{3}$ FRESTON, P. Protestantes e política no Brasil: da Constituinte ao impeachment. Tese (Doutorado em Sociologia) - Campinas, UNICAMP, 1993.
} 
palavra cristão. A palavra "cristão" antecedida pelo radical grego "pseudo", até poderia ser usado nos círculos teológicos, mas por parecer emitir um juízo de valor, é preferível ser evitada na academia, embora esteja se tornando comum no cotidiano não acadêmico. O radical "iso" significa "igual", "semelhante" ou "parecido". Esses grupos seriam iguais no sentido de "semelhantes", seriam apenas parecidos com os grupos cristãos, mas não o são.

Ao se frequentar a IURD e a IMPD e assistir os seus cultos, há em todo o momento ataques ferrenhos ao Espiritismo, ao Umbandismo, ao Candomblé, ao Catolicismo e até aos grupos protestantes. Durante os exorcismos, há um clima exasperado de hostilidade, de coerção, e manipulação, de exercício de poder, de cerceamento de liberdade. Também há ataques e agressões físicas aos seguidores dos cultos afro ${ }^{4}$. Nesse relacionamento dessas "igrejas" com outros grupos religiosos, há uma espécie de fanatismo religioso que surge como consequência de uma insegurança interior, lançando elementos de demonização. A suspeita e o ódio que aparecem nas relações com as outras religiões são um resultado do mesmo receio que produziu bruxas e a caça às heresias na cristandade medieval. É um genuíno temor ao demoníaco e, deste modo, não pode ser sobrepujado por um ideal de tolerância que esteja fundamentado em insensibilidade ou numa minimização abstrata das diferenças.

Destarte, o traço comum na teologia dos grupos Isocristãos é a demonologia, que se torna o elemento principal na interpretação da vida e da fé religiosa, ao redor do qual gravitam todos os demais elementos. A demonologia está presente no dia-a-dia em todas as experiências dos membros, obreiros e pastores, dando um sentido de unidade, um sentido totalizante para o crente e suas experiências, além de dar uma profunda coerência para os participantes. Essa experiência da totalidade, de algo pleno de sentido, absoluto, dá àquele que a vivencia uma coerência tal que extrapola dados lógicos ou objetivos e concilia aspectos aparentemente irreconciliáveis numa dimensão totalizante.

\footnotetext{
${ }^{4}$ Aspecto amplamente investigado no primeiro capítulo da tese de doutorado em Ciências da Religião de Jaziel Guerreiro Martins pela Universidade Metodista de São Paulo em 2005.
} 
O diabo é a peça fundamental na teodiceia isocristã: ele compõe o papel do inimigo identificado, assume o lócus social da diferença e da oposição num contexto de guerra santa em que o conteúdo paranoico persecutório figura na atitude fundamentalista da IURD e da IMPD em relação a outros segmentos religiosos. A demonização da diferença religiosa por parte do isocristianismo pode ser entendida como uma forma de afirmação de poder do próprio grupo no campo religioso brasileiro, que é extremamente pluralizado; é uma forma de afirmação da identidade do grupo, pois a negação do outro se torna a afirmação do próprio eu.

Os grupos Isocristãos, na verdade, devem boa parte de sua expansão ao personagem “diabo”. É nele que os diversos infortúnios financeiros da vida cotidiana encontram um sentido de existência. É ele que opera a desgraça financeira, o desemprego, os baixos salários, enfim, o sofrimento do povo brasileiro. E, para se livrar do maligno e de todo o mal que ele produz, Deus levantou uma igreja forte, poderosa, que luta veementemente contra o reino das trevas: E como a demonologia é o eixo principal de toda a teologia dessas Isoigrejas, é preciso analisá-la teologicamente. E, nada melhor do que a ideia de Paul Tillich sobre o "demônico”.

\section{Avaliação da Demonologia Isocristã à Luz do Pensamento de Paul Tillich sobre o "Demônico"}

Paul Johannes Tillich nasceu a 20 de agosto de 1886 em Starzeddel, Alemanha Setentrional. Tillich iniciou os estudos universitários em Berlim, dando sequência aos mesmos em Tübingen para a láurea de filosofia e em Halle para a láurea de teologia. Em teologia, esteve na escola de um dos maiores mestres da época, Martin Kähler, o qual valendo-se da distinção feita pela língua alemã entre Historie (crônica histórica) e Geschichte (História), mostra que os Evangelhos não podem ser considerados como documentos de crônica histórica da vida de Jesus, mas apenas como documentos históricos da mensagem pregada pela igreja primitiva, ou seja, do kerygma. Este contém o Cristo histórico, mas não nos permite reconstruir fielmente os acontecimentos de sua vida, mas só o testemunho prestado pela Igreja a Jesus como o Cristo. 
Essa distinção entre o Cristo histórico e o Cristo da crônica histórica influenciou profundamente o pensamento de Paul Tillich sobretudo no que se refere aos episódios particulares da vida de Cristo.

A produção de Tillich é considerável: mais de quatrocentos escritos, divididos do ponto de vista cronológico em dois grupos: alemão e norteamericano. Dentre essas obras, The shaking of Foundations ${ }^{5}$ ( $\mathrm{O}$ abalo das fundações) e The new Being ${ }^{6}$ (O novo ser) foram as que tiveram maior sucesso e exerceram a maior influência. Para os especialistas em teologia, ele elaborou a monumental Teologia Sistemática, uma autêntica suma teológica, obra que Ihe custou quarenta anos de esforços. Também foram elaborados dois livros publicados postumamente para os teólogos: História do pensamento cristão e Perspectivas da teologia protestante nos séculos XIX e XX.

O eixo em torno do qual gira toda a teologia tillichiana é o princípio da correlação. O princípio da correlação afirma a necessidade de pensar qualquer realidade juntamente com outra realidade, na medida em que elas se encontram em relação de dependência recíproca. Segundo o princípio de correlação, os elementos relacionados só podem existir juntos, razão pela qual é impossível que um aniquile a existência do outro. Por exemplo, o eu não

\footnotetext{
${ }^{5} \mathrm{~A}$ tese dessa obra é que os símbolos, os conceitos e a linguagem com que a mensagem cristã é hoje expressa estão decididamente superados: o homem moderno não os compreende mais. Nem mesmo os símbolos mais importantes, como Deus, pecado, paraíso e inferno, dizem-lhe ainda alguma coisa e, ao invés de ajudá-lo a crer, tornaram-se para ele uma ulterior razão de incredulidade. Chegou, portanto, o momento de abandoná-los e substitui-los por símbolos novos, em conformidade com o novo modo de pensar. Tillich, então, dá a partida à realização de seu grande programa de "transmitização" do cristianismo, que é constituído de duas partes: a) desmitologização, em que se despe o kerygma das vestes expressivas tradicionais; b) remitização, em que se lhe dá vestes novas e atuais. O autor demitiza o conceito tradicional de Deus como ser supremo e o remitiza com o conceito de "fundamento do ser". ${ }^{6}$ A tese dessa obra é que, se Cristo é apresentado como Novo Ser, a Nova Realidade, a Nova Criação, a mensagem cristã voltará a atrair também o homem moderno. Segundo Tillich, para que o Novo Ser possa readquirir a eficácia que tinha quando se manifestou há dois milênios, é preciso libertá-lo dos esquemas mentais em que foi fechado, das práticas supersticiosas de que foi circundado através dos séculos e restituir-Ihe sua originalidade. Isso pode ser feito através do conceito do "Novo Ser". Paul Tillich também opera uma terceira transmitização em Love, power and justice: esta tem por objeto o Espírito Santo, para o qual o autor escolhe a expressão "poder do amor". No poder do amor se resolvem todas as expressões humanas do amor: libido, eros, philia e agape.
} 
pode existir sem o mundo, nem o mundo sem o eu; a filosofia não pode existir sem a teologia, nem a teologia sem a filosofia; a fé não pode existir sem a dúvida, nem a dúvida sem a fé. É impossível um oposto solitário, tanto no ser como no pensamento. Isto significa que os opostos não são distintos até o fim, mas que há um ponto de encontro. E do ponto de encontro nasce a unidade das coisas cujo ser é tecido de correlações.

O pensamento de Tillich começou a encontrar admiradores e seguidores. Depois da Segunda Guerra, eles cresceram tanto a ponto de fazer dele o teólogo mais admirado e influenciado dos Estados Unidos. Em 1955, a Universidade de Harvard ofereceu-lhe um lugar entre seus estudiosos que trabalham nas fronteiras da ciência. Em 23 de setembro de 1962, recebeu o Prêmio da Paz das mãos do presidente da Associação dos Editores Alemães. Morreu em 22 de outubro de 1965 em Chicago. ${ }^{7}$

Um de seus pensamentos pode ser usado para fazer uma comparação com a demonologia das igrejas isocristãs: é a análise da ideia do demônico ${ }^{8}$. Não se pode compreender sua argumentação sobre o tema, sem antes analisar seu pensamento sobre as várias funções básicas da vida e a natureza de sua

\footnotetext{
${ }^{7}$ Em 1993 foi fundado o Grupo de Pesquisa Paul Tillich por um grupo de professores e alunos do Curso de Pós-Graduação em Ciências da Religião da Universidade Metodista de São Paulo, que passou a reunir docentes e discentes interessados no estudo do pensamento de Paul Tillich e na sua atualização no mundo de hoje. Os participantes do primeiro simpósio, realizado em novembro de 1994, decidiram instituir uma Associação Científica, com o nome de Sociedade Paul Tillich do Brasil, especialmente encarregada de organizar os seminários anuais e de manter contatos com os interessados no Brasil e com as associações semelhantes nos Estados Unidos, na Alemanha, nos países de língua francesa e na Holanda. Deve ser ressaltada a participação em eventos e congressos organizados por essas associações, a troca regular de informações e a doação de obras importantes para o arquivo, sendo um de seus principais representantes o Dr. Etienne Alfred Higuet.

${ }^{8} \mathrm{Em}$ sua linguagem, Paul Tillich parece ser um tanto ambíguo à primeira vista, mas analisando com cuidado o seu pensamento, pode-se perceber pelo contexto que há uma sutil e, às vezes, uma imperceptível diferenciação entre o "demônico" e o "demoníaco". No original de Tillich, tanto inglês quanto alemão, só há uma palavra: demonic e dämonisch. $\mathrm{O}$ francês e as outras línguas neolatinas têm a possibilidade de usar duas palavras: demoníaco, no sentido de satânico, e demônico, no sentido de ambíguo, criador/destruidor ao mesmo tempo. Usa-se em particular para expressar a ambiguidade do numinoso, na linha de Otto: tremendum et fascinosum. Ou: fundamento e abismo do ser, ao mesmo tempo. Assim sendo, o termo "demônico" será sempre usado para demonstrar a ambiguidade "divino-demônico"; por sua vez, "demoníaco" sempre será utilizado no sentido negativo da ideia, podendo ser sinônimo de "satânico".
} 
ambiguidade, que ele trata no quarto capítulo de sua Teologia Sistemática. Para ele, a vida é a atualização do ser potencial e, em todo processo vital ocorre essa atualização. A vida sempre se dirige ao novo. Dentro do processo de atualização do potencial, que é chamado de vida, ele distingue três funções básicas da vida: autointegração, sob o princípio de centralidade, autocriação sob o princípio de crescimento, e autotranscendência sob o princípio da sublimidade ${ }^{9}$.

Essas três funções da vida unem elementos de autoidentidade com elementos de autoalteração. Mas essa unidade está ameaçada pela alienação existencial, que leva a vida em uma ou outra dimensão, aniquilando assim a unidade. Na medida em que essa destruição é real, a autointegração é oposta pela desintegração, a autocriação é oposta pela destruição, a autotranscendência é oposta pela profanação e demonização. Daí Tillich conclui que todo processo de vida apresenta a ambiguidade de elementos positivos e negativos amalgamados de tal forma que se torna impossível apartar o negativo do positivo: a vida é ambígua em cada momento. A vida não é essencial, nem existencial, mas ambígua ${ }^{10}$.

Dentro da autotranscendência da vida e suas ambiguidades, Tillich fala das ambiguidades da religião: o sagrado e o secular e, o divino e o demônico ${ }^{11}$. A religião sempre se move entre os pontos ameaçadores de profanação e demonização, e em todo ato genuíno da vida religiosa ambas estão presentes, aberta ou disfarçadamente. A característica principal do demônico é o estado de ser desintegrado. A autoelevação demoníaca de uma nação sobre todas as outras em nome de seu Deus ou sistema de valores produz a reação de outras nações em nome de seu Deus. A auto elevação demoníaca de forças particulares na personalidade centrada e a reivindicação de sua superioridade absoluta conduzem à reação de outras forças e uma consciência desintegrada.

E, poderíamos indagar: a partir do pensamento de Tillich, como se verificaria isso na demonologia desses grupos isocristãos? Os ataques severos a outros grupos religiosos antagônicos, os ataques e agressões físicas aos

\footnotetext{
9 TILLICH, P. Teologia Sistemática. São Paulo: Paulinas \& Sinodal, 1984. p. 408.

10 TILLICH (1984. p. 409).

11 TILLICH (1984. p. 458-466).
} 
seguidores dos cultos afro e todo o "exorcismo" praticado de forma hostil com uma espécie de fanatismo religioso lançando elementos de demonização, fazem com que, em uma linguagem Tillichiana, se asseverar peremptoriamente que esses dois grupos religiosos tornam-se então, demônicos ${ }^{12}$.

A esta altura é preciso verificar como Tillich trata do símbolo do demônico na linguagem teológica. De acordo com o autor, tal símbolo não necessita de justificação como em algumas décadas antes dele produzir sua obra Teologia Sistemática. Pode-se perfeitamente entender a argumentação de Tillich, haja vista o termo ter se tornado muito usado e abusado para designar forças antidivinas na vida individual e social. Dessa forma, ele frequentemente acabou perdendo o caráter ambíguo implícito na própria palavra, passando a representar uma visão exclusivamente mitológica ${ }^{13}$.

Essa é a visão isocristã desse símbolo do demônico, pois propagam eles a tempo e fora de tempo uma visão mitológica: demônios seriam seres divinoantidivinos. Na visão da IURD e da IMPD, bem como em boa parte da visão tradicional cristã, eles não seriam meramente negações do divino, mas participariam de maneira distorcida no poder e santidade do divino. Possuem força e poder à semelhança da divindade, tanto que se opõem a ela. Em contra/posição, na argumentação de Tillich esse termo deve ser entendido contra um pano-de-fundo mitológico.

Ao desenvolver uma leitura do mal a partir da ambiguidade divinodemônica, Paul Tillich leva em conta o processo de secularização e interpretação da origem do mal a partir do Iluminismo. Ele procura distinguir entre a relação do demônico e do profano com o divino. O demônico não resiste à autotranscendência como o profano, mas distorce a auto transcendência identificando um portador particular de santidade com o próprio sagrado. Nesse sentido, todos os deuses politeístas seriam demoníacos, porque a base de ser e sentido sobre o qual eles se apoiam é finita, não importando quão sublime, amplo ou dignificada ela possa ser. E a reivindicação de algo finito querer ser infinito ou de aspirar a grandeza divina

\footnotetext{
12 Não confundir com "demoníacos". TILLICH (1984, p. 464).

13 TILLICH (1984, p. 463).
} 
é a característica do demoníaco. Demonização do sagrado ocorre em todas as religiões, dia após dia, mesmo naquela religião que se baseia na autonegação do finito na cruz do Cristo. A procura da vida sem-ambiguidade é, consequentemente, apontada mais radicalmente contra a ambiguidade do sagrado e demoníaco no reino religioso ${ }^{14}$.

O trágico é a ambiguidade intrínseca à grandeza humana. Mas o objeto da tragédia não aspira à grandeza divina. Ele (o trágico) não pretende ser como "Deus". Ele toca, por assim dizer, a esfera divina, é rejeitado por ela e lançado à autodestruição, mas não reivindica divindade para si mesmo. Onde quer que isso seja feito, aparece o demônico. A característica principal do trágico é o estado de ser cego; a característica principal do demônico é o estado de ser desintegrado.

Isso é facilmente compreensível à base da reivindicação demoníaca de divindade sobre um apoio finito: a elevação de um elemento da finitude à condição de poder e sentido infinitos necessariamente produz a reação de outros elementos da finitude, que negam essa reivindicação ou a buscam para si mesmos. A autoelevação demoníaca de uma nação sobre todas as outras em nome de seu Deus ou sistema de valores produz a reação de outras nações em nome de seu Deus.

Nas religiões isocristãs, a autoelevação demoníaca de forças particulares na personalidade centrada e a reivindicação de sua superioridade absoluta conduzem à reação de outras forças e a uma consciência desintegrada. A reivindicação de um valor, representado por um Deus, de ser o critério de todos os outros grupos, conduz às desintegrações das religiões politeístas. ${ }^{15}$ Daí, uma consequência dessas desintegrações nesses grupos religiosos relacionada com a natureza do demônico, é o estado de ser "possuído" pelo poder que produz a ruptura. Os demoníacos são os possessos. A liberdade da centralidade é eliminada pela ruptura demoníaca. Estruturas demoníacas na vida comunitária e pessoal não podem ser rompidas por atos de liberdade e boa-vontade. Elas são até fortalecidas por esses atos

\footnotetext{
${ }^{14}$ TILLICH (1984).

${ }^{15}$ TILLICH (1984).
} 
- exceto quando o poder de mudar procede de uma estrutura divina, isto é, uma estrutura de graça.

Toda vez que aparece o demônico, ele mostra traços religiosos, mesmo que a aparência seja moral ou cultural. Essa é uma consequência lógica da imanência mútua das três funções da vida na dimensão do espírito e do duplo conceito de religião como preocupação incondicional e como reino de símbolos concretos que expressam preocupações concretas. Também aqui pode se dar como exemplo a IURD e a IMPD: as exigências incondicionais de obediência cega feitas pelos pastores que se auto atribuem dignidade religiosa, bem como pelas funções culturais, sociais, políticas e religiosas que dominam todas as outras por esses líderes que buscam a idolatrização de si mesmos, por impulsos particulares na pessoa que se apodera do centro pessoal - em todos esses casos ocorre uma autotranscendência distorcida ${ }^{16}$.

Ao usar esse pensamento de Tillich na análise da demonologia dos grupos religiosos isocristãos, pode-se ver claramente uma forma marcante na ambiguidade do demônico na esfera do reino religioso. A IURD e a IMPD, especialmente aquela cujo crescimento tem sido reconhecido universalmente, e poderosamente se constitui em termos políticos e econômicos, se tornou possuída demonicamente quando se revestiu de santidade divina e produziu a ruptura que conduziu à luta antidemônica contra os grupos religiosos afrobrasileiros e até de outros segmentos cristãos, bem como fomentou uma perseguição demoníaca ideológica implacável, usando, em alguns casos, até a força física destruindo espaços cúlticos dessas religiões.

Essa atitude fornece uma transição à discussão da religião no sentido mais estrito da palavra e da sua demonização, de acordo com a metodologia da ambiguidade de Paul Tillich. A ambiguidade básica da religião tem uma raiz mais profunda do que qualquer das demais ambiguidades da vida, pois religião é o ponto no qual é recebida a resposta à busca do que é sem ambiguidade. $A$ religião, nesse sentido, (isto é, no sentido da possibilidade de o ser humano receber essa resposta) é sem-ambiguidade; a recepção real, de fato, é profundamente ambígua, pois ocorre nas formas cambiantes da existência

${ }^{16}$ TILLICH (1984, p. 464). 
moral e cultural do homem. Essas formas participam do sagrado ao qual apontam, mas não são sagradas em si mesmas. Se elas reivindicam ser sagradas em si mesmas, acabam se tornando demoníacas exatamente por causa disso ${ }^{17}$.

Tillich dá alguns exemplos da demonização da religião em geral. A religião como realidade histórica utiliza criações culturais tanto na teoria quanto na práxis. Usa algumas e rejeita outras, e ao fazer isso constitui um reino de cultura religiosa que se estabelece paralelamente às outras criações culturais. Mas a religião como autotranscendência da vida em todos os reinos reivindica uma superioridade sobre elas que se justifica na medida em que a religião assinala para aquilo que transcende a todas elas, mas a reivindicação de ascendência se torna demoníaca quando a religião como realidade social e pessoal faz essa reivindicação para si mesma e para suas formas finitas mediante as quais ela aponta ao infinito ${ }^{18}$.

Para Tillich, a religião é atual em grupos sociais que estão unidos a grupos políticos ou separados deles. Em ambos os casos elas constituem uma realidade social, legal e política que é consagrada pelo sagrado incorporado nelas. No poder dessa consagração, elas consagram as outras estruturas comunitárias e, dessa forma, tentam controlá-las. No caso de resistirem, elas procuram destruí-las.

Assim, analisando-se a estrutura e todo o sistema da IURD e da IMPD, nota-se que o poder dos portadores do sagrado é o caráter incondicional do sagrado, em cujo nome elas rompem a resistência de todos aqueles que não aceitam os símbolos da autotranscendência sob os quais vive a comunidade religiosa isocristã. Essa é a fonte do poder daqueles que representam uma comunidade religiosa, como é também a fonte da solidariedade das instituições sagradas, costumes sagrados, sistemas de lei divinamente ordenados, ordens hierárquicas, mitos e símbolos, e assim por diante ${ }^{19}$. Mas essa mesma solidez traz sua ambiguidade divino-demônica; esta é capaz de rejeitar todas as críticas que são levantadas contra ela em nome da justiça.

\footnotetext{
17 TILLICH (1984).

${ }^{18}$ TILLICH (1984, p. 464-465).

${ }^{19}$ TILLICH (1984, p. 465).
} 
Dessa forma, ao se olhar para esses grupos sob esse prisma tillichiano, entende-se o fato dela rejeitar as críticas em nome do sagrado, que tem o princípio de justiça dentro de si mesmo, tentando destruir as mentes e a religião daqueles que tentam resistir.

No reino da vida pessoal, a ambiguidade divino-demônica da religião aparece na ideia de santo. Aqui se reflete o conflito entre humanidade e santidade, e o apoio divino, bem como a supressão demoníaca do desenvolvimento pessoal em direção à humanidade. Esses conflitos, com suas consequências integradoras, desintegradoras, criativas e destrutivas ocorrem antes de tudo dentro da pessoa individual. Uma das formas através das quais a religião usa sua própria ideia consagrada de personalidade para suprimir a ideia de humanidade no indivíduo é criando uma consciência intranquila naquele que não aceita a reivindicação absoluta da religião. O psicanalista conhece a devastação causada por esse conflito no desenvolvimento pessoal $^{20}$.

Nessas igrejas isocristãs, essa consciência intranquila se verifica no seu discurso demonológico. Se no olhar de Tillich a ambiguidade divino-demônica da religião aparece na ideia de santo, na IURD e na IMPD o "liberto" dos demônios é o santificado por Deus, haja vista o liberto ser o correlato de "santo" da teologia protestante de sua época. Usam sua própria ideia consagrada de personalidade, "o liberto de Satanás", para suprimir a ideia de humanidade no indivíduo, criando uma consciência extremamente intranquila naquele que não aceita a reivindicação absoluta da igreja.

Frequentemente, na história da religião, é o princípio negativo, ascético que recebe consagração religiosa e que se coloca como juiz condenador contra as implicações positivas da ideia de humanidade. Mas o poder contido na imagem religiosa de santidade pessoal não existiria se não houvesse o outro lado - o impacto sobre o desenvolvimento da pessoa, proveniente do caráter divino, antidemoníaco do sagrado ao qual a religião aponta. Mas devemos dizer novamente que a resposta à busca da vida sem-ambiguidade não está na ideia de santo nem na ideia do liberto dos demônios, embora a resposta possa

\footnotetext{
${ }^{20}$ TILLICH (1984).
} 
ser recebida somente na profundidade da personalidade autotranscendente - religiosamente falando, no ato de fé.

A discussão sobre a ambiguidade divino-demônica na relação da religião como teoria naturalmente enfoca o problema da doutrina religiosa, particularmente quando essa aparece na forma de um dogma estabelecido. 0 conflito que surge na IURD e na IMPD é um conflito entre a verdade consagrada do dogma demonológico e a verdade que une mudança dinâmica e forma criativa. Mas não é o conflito teórico como tal no qual aparece a ambiguidade divino-demônica, mas em seu significado para a comunidade santa e a personalidade santa. A supressão demoníaca da obediência honesta às estruturas da verdade é que está em jogo aqui. O que ocorre nesse sentido à função cognitiva acontece igualmente à função estética; a supressão da expressividade autêntica na arte e literatura é igual à supressão do conhecimento honesto. É feito em nome de uma verdade consagrada religiosamente e de um estilo consagrado religiosamente ${ }^{21}$.

Não há dúvida de que a autotranscendência abre os olhos à verdade cognitiva e à autenticidade estética. Poder divino se encontra nas doutrinas religiosas e na arte religiosa. Mas começa a distorção demoníaca quando uma nova percepção irrompe na superfície e é reprimida em nome do dogma, da verdade consagrada, ou quando novos estilos buscam exprimir as tendências de um período e são impedidos de fazê-lo em nome de formas de expressão religiosamente aprovadas. Em todos esses casos a comunidade e as personalidades que resistem são vítimas da destruição demoníaca da verdade e expressividade em nome do sagrado. O isocristianismo vê dessa maneira as comunidades afro-brasileiras, o catolicismo romano e as igrejas protestantes históricas, bem como todos os seus seguidores como aqueles que, por terem pactos com o diabo, resistem aos seus dogmas e aos seus avanços. Em nome de suas crenças (dogmas) os isocristãos demonicamente tentam destrui-los

\footnotetext{
21 TILLICH (1984, p. 466).
} 
em nome de seu Deus. É preciso destrui-los, pois participam do "eixo do mal".22

Numa perspectiva Tillichiana, a IURD e a IMPD que se julgam como a representante maior do Reino de Deus em sua luta contra as forças da demonização, estão elas mesmas sujeitas às ambiguidades da religião e expostas à demonização. Como pode, então, aquilo que é demonizado representar a luta contra o demoníaco? Tillich responderia essa indagação mostrando que todas as igrejas cristãs são profanas e sublimes, demônicas e divinas, numa unidade paradoxal. A expressão desse paradoxo é a crítica profética das igrejas pelas próprias igrejas ${ }^{23}$. Algo numa igreja reage contra essa distorção da igreja como um todo. Sua luta contra o demônico é dirigida contra o demoníaco na própria igreja. Essa luta pode levar a movimentos de reforma, e é a existência desses movimentos que confere às igrejas o direito de considerar-se a si próprias como veículos do Reino de Deus, lutando na história, incluindo aqui a história das igrejas.

Ao se analisar o desenvolvimento da leitura do mal a partir da categoria da ambiguidade estabelecida por Tillich, pode se confrontar a interpretação da IURD e da IMPD que propagam a superação da ambiguidade pela realização dos exorcismos. A ambiguidade divino-demônico, enraizada na separação e interação de elementos essenciais e existenciais do ser, encontraria a reunião desses elementos através dos exorcismos. Na visão de Tillich, ao contrário, a superação é realizada sempre pela “presença espiritual” criadora da fé e do amor, de onde se origina uma exigência ética radical ${ }^{24}$.

Na pregação “iurdiana” e "mundialista”, tanto em nível de púlpito quanto nos seus materiais escritos e programas televisivos, o exorcismo é sempre uma exigência para se conseguir uma vida saudável e feliz, equilibrada, unida à divindade; a manifestação da união transcendente se faz pela quebra

\footnotetext{
${ }^{22}$ Expressão usada pelo presidente norte-americano George W. Bush ao referir-se à Coréia do Norte, Iraque e Paquistão por representarem "perigo" à humanidade e por isso, em nome de Deus, esses países são anematizados por ele, que é o "xerife justiceiro" de Deus aqui na Terra.

${ }^{23}$ Tillich (1984, p. 468.

${ }^{24}$ TILLICH (1984, p. 483-505).
} 
de pactos com o diabo e dos atos de exorcismos. Sendo a libertação do diabo o poder e o meio dessa união transcendente, não é difícil encontrar nessas duas isoigrejas uma demonologia que chegue a ocupar todo o espaço da teologia como discurso sobre Deus, o divino e o sagrado. Daí que os rituais de libertação são centrais na sua teologia, pois a evidência de que uma Igreja seja verdadeira e cheia do Espírito Santo se atesta pelo exorcismo, pelo poder que os pastores possuem sobre os demônios.

Partindo-se da análise de Tillich, pode-se afirmar que o discurso religioso se concentra naquele algo que para o grupo é fundamental para se atingir a superação da vida sem-ambiguidade. Todo o discurso é definido em relação à atuação dos demônios: o fiel deve frequentar as reuniões de libertação para se ver livre do diabo; deve procurar o batismo com o Espírito Santo para escapar da habitação dos espíritos malignos. Andar em santidade significa ser libertado de Satanás e seus demônios e não ter qualquer ligação com eles. Deve-se ler a Bíblia para usá-la como arma eficaz no combate a Satanás. A frequência às reuniões alimentará as almas dos fiéis com a palavra da verdade, a qual os arma contra as ciladas de Satanás. Tudo gira em torno do discurso demonológico. As Igrejas isocristãs veem, portanto, a superação da ambiguidade única e exclusivamente na expulsão dos demônios de seus frequentadores.

A pregação denunciadora da ação diabólica e a prática do exorcismo atraem uma multidão de vítimas sociais marcadas para a exclusão ${ }^{25}$ : são pessoas vivendo num abismo existencial entre essência e existência. Pessoas despojadas dos direitos humanos à moradia digna, ao salário justo, à assistência médica, à educação, ao sistema de saúde; gente corroída pelos desejos insatisfeitos e pelos sentimentos negativos de incapacidade, inferioridade e desvalor; outros atormentados por sintomas de enfermidades várias ou angustiadas com problemas nas relações familiares, acorrem pressurosas ao anúncio da boa nova de que, com a expulsão dos demônios, seus males se acabarão e uma nova vida de abundância estará a seu alcance. Serão salvas do demônio que as amarra, pois todas essas intempéries são causadas por ele. É a busca da superação da ambiguidade.

\footnotetext{
25 OLIVA, M. O diabo no reino de Deus: por que proliferam as seitas? São Paulo: Musa, 2007. p. 146.
} 


\section{Considerações finais}

Diferentemente da demonologia isocristã, a argumentação de Tillich está baseada sob o fato de que a criação da vida sem ambiguidade resulta na reunião dos elementos essenciais e existenciais do ser humano nos processos da vida, em que o ser atual é a verdadeira expressão do ser potencial, que é realizada somente depois de alienação, resistência e decisão. Na reunião do ser essencial com o ser existencial, a vida ambígua é elevada por cima de si mesma, até uma transcendência que não poderia obter por seu próprio poder. A "união transcendente", que é uma qualidade de vida sem ambiguidade aparece no espírito humano como o movimento extático que a partir de um ponto de vista é chamado de "fé" e a partir de outro ponto de vista é chamado de "amor". ${ }^{26}$

Dentro desse raciocínio, a fé é o estado de ser possuído pela unidade transcendente da vida sem ambiguidade e inclui o amor como o estado de ser introduzido nessa unidade transcendente. Dessa análise fica óbvio que a fé logicamente precede o amor, embora na realidade nenhum deles possa existir sem o outro. Fé sem amor é uma continuação da alienação e é um ato ambíguo de autotranscendência religiosa. Amor sem fé é uma reunião ambígua daquilo que está separado, sem o critério e o poder da união transcendente ${ }^{27}$.

Enquanto na IURD e na IMPD as marcas da influência espiritual são os rituais de libertação e os exorcismos, na comunidade espiritual proposta por Tillich as marcas são sempre a fé e o amor. Nas igrejas isocristãs a evidência de que uma Igreja é forte e verdadeira se atesta pelos exorcismos, pelo poder que a igreja possui sobre os demônios; no entanto, a comunidade espiritual,

\footnotetext{
26 TILLICH (1984, p. 484).

27 Essas afirmações pressupõem uma discussão ampla de fé e amor para serem inteligíveis. Paul Tillich trata da fé no livro Dinâmica da fé e do amor em outro livro Amor, poder e justiça. A tarefa nesta tese não é esta, mas sim, determinar o lugar dos dois conceitos dentro do sistema teológico de Tillich e mostrar dessa forma sua relação com outros conceitos teológicos e símbolos religiosos e comparar com o sistema teológico da Igreja Universal do Reino de Deus.
} 
latente ou manifesta, no entender de Tillich, é a comunidade do Novo Ser. É criada pelo Espírito divino tal como manifesta no Novo Ser em Jesus como o Cristo. Essa origem determina o seu caráter: ela é a comunidade de fé e de amor $^{28}$. As igrejas seriam, simultaneamente, a atualização e a distorção da Comunidade Espiritual.

O termo "comunidade de fé" utilizado por Tillich indica a tensão entre a fé do membro individual e a fé da comunidade como um todo. Faz parte da natureza da Comunidade Espiritual o fato de que essa tensão não leva a uma ruptura. A presença Espiritual mediante a qual o indivíduo é possuído no ato de fé transcende condições individuais, crenças e expressões de fé. Ela o une a Deus que pode impactar os homens mediante todas as condições, mas que não se limita a nenhuma delas. A Comunidade Espiritual contém uma variedade sem fim de expressões de fé e não exclui nenhuma delas; está aberta em todas as direções porque se baseia na manifestação central da Presença Espiritual. É fé, contudo, superando o abismo intransponível entre o finito e o infinito; é fragmentária em cada instante, e antecipação parcial da união transcendente da vida sem ambiguidade.

Como comunidade do Novo Ser, a Comunidade Espiritual é uma comunidade de amor, que contém a tensão entre a variedade infinita de relações de amor e o ágape, que une o ser com ser na união transcendente da vida sem ambiguidade. Essa variedade de relações de amor não impede que o ágape una os centros separados nessa união transcendente. Contudo, o amor

é multidimensional; não se fragmente pro conta das separações do tempo e do espaço; é antes uma antecipação da união perfeita na Vida Eterna. A Comunidade Espiritual é santa, participando mediante a fé e através do amor, da santidade da Vida Divina, e confere santidade às comunidades religiosas das quais ela é a essência espiritual invisível.

\section{Referências}

BITTENCOURT FILHO, J. Novos movimentos religiosos na igreja e na sociedade. São Paulo: Edições Ave Maria, 1996.

${ }^{28}$ TILLICH (1984, p. 503). 
BITTENCOURT FILHO, J. Matriz religiosa brasileira: religiosidade e mudança social. Petrópolis/Rio de Janeiro: Vozes/KOINONIA, 2003.

CAMPOS, L. S. Teatro, templo e mercado: organização e marketing de um empreendimento neopentecostal. Petrópolis: Vozes, 1997.

FRESTON, P. Protestantes e política no Brasil: da Constituinte ao impeachment. 1993. Tese (Doutorado em Sociologia) — Universidade Estadual de Campinas, 1993.

HORTAL, J. A Igreja e os novos grupos religiosos: estudos da CNBB 68. São Paulo: Paulinas, 1993.

MARIANO, R. Mudanças no campo religioso brasileiro no Censo 2010. Debates do NER, v. 2, n. 24, 2013.

MARTINS, J. G. Sai Satanás: a demonologia e a demonopráxis como eixo hermenêutico principal da Igreja Universal do Reino de Deus. Tese (Doutorado em Ciências da Religião) - São Bernardo do Campo, Universidade Metodista de São Paulo (UMESP), 2005 .

OLIVA, M. O diabo no reino de Deus: por que proliferam as seitas? São Paulo: Musa, 2007.

ORO, A. P.; TADVALD, M. A Igreja Universal do Reino de Deus no espaço público religioso global. Sociologia: Revista da Faculdade de Letras da Universidade do Porto, v. XXXVI, p. 51-69, 2018. DOI: 10.21747/08723419/soc36a3

TILLICH, P. Teologia Sistemática. São Paulo: Paulinas \& Sinodal, 1984.

TILLICH, P. História do pensamento cristão. Trad. Jaci Maraschin. São Paulo: STE, 1988.

TILLICH, P. Perspectivas da Teologia Protestante nos séculos XIX e XX. Trad. Jaci Maraschin. São Paulo: ASTE, 1986.

TILLICH, P. A Era Protestante. Trad. Jaci Maraschin. São Bernardo do Campo: Ciências da Religião e Traço a Traço Editorial, 1992.

TILLICH, P. Amor, poder e justiça. São Paulo: Novo Século, 2004. 